\title{
PEMBUATAN PERMEN SUSU KAMBING ETAWA DENGAN MENGGUNAKAN BUAH KURMA SEBAGAI PENGGANTI GULA
}

\author{
Farida Amir ${ }^{1)}$, Eka Noviani ${ }^{1)}$, dan Nyoman Sri Widari ${ }^{1)}$ \\ ${ }^{1)}$ Fakultas Teknik Prodi Teknik Kimia \\ Universitas WR. Supratman \\ Email: faridaamirr93@gmail.com
}

\begin{abstract}
Abstrak
Permen merupakan suatu produk pangan yang disukai semua orang mulai dari anakanak hingga orang dewasa. Permen dapat menjadi peluang bisnis yang menguntungkan, tetapi karena permen ini sangat umum dikonsumsi, orang jarang memperhatikan kandungan gizi permen. Penelitian bertujuan untuk menciptakan inovasi baru dari susu kambing agar dapat dikonsumsi dalam jangka waktu yang panjang serta memanfaatkan buah kurma sebagai pemanis alami dalam pembuatan permen. Bahan baku pada pembuatan permen sangat sederhana diantaranya gula, sirup glukosa dan air, selain itu ada juga bahan tambahan lain tergantung pada jenis permen yang dibuat. Pada pembuatan permen sebagai variabel tetapnya adalah dengan penambahan gula 50 gram dan sirup glukosa 100 gram sedangkan variabel berubahnya adalah berat susu kambing segar 50, 100, dan 150 (gram) dan buah kurma yang sudah bebas dari kulit dan biji 50, 100, 150, dan 200 (gram). Hasil penelitian menunjukkan hasil analisis terbaik berada pada perbandingan susu kambing etawa segar 50 gram dan jumlah kurma 200 gram dengan hasil analisis gula reduksi 18,46\%, total sukrosa 76,05\%, kadar air 1,53\%, kadar protein 1,05\%, kadar abu 0,5\%. Sedangkan hasil uji organileptik dengan melibatkan 50 orang panelis, 95\% suka dengan warna permen, 75\% suka dengan aromanya, dan 80\% suka dengan rasa.
\end{abstract}

Kata kunci: Kurma, Permen, Susu Kambing Etawa

\begin{abstract}
Chewing is a food product like everyone from children to adults. Chewing can be a lucrative business opportunity, but because it is very common sweets are consumed, people rarely pay attention to the nutritional content of candy. This study aims to create a new innovation from goat's milk to be consumed in the long term as well as utilizing palm fruit as a natural sweetener in candies. The main material to make this candy is very simple such as sugar, glucose syrup, and water. The fixed variables that is used to make the candy are adding 50 grams of sugar and 100 grams of syrup glucose. The changed variables are adding 50 grams, 100 grams, and 150 grams weight of the goat fresh milk and also adding 50, 100, 150, and 200 grams of kurma fruit that already peeled and without seeds. From the study the best mixture that can get is from ratio of 50 gram of etawa goat fresh milk and 200 grams of kurma fruit. The result of sugar reduction is $18.46 \%$, $76.05 \%$ total sucrose, $1.53 \%$ wet wieght, $1.05 \%$ protein, $0.5 \%$ of ash. The result of organileptic test with 50 panelists, $95 \%$ like the color of the candy, $75 \%$ like of the smell, and $80 \%$ like the flavor of the candy.
\end{abstract}

Keywords: Kurma Fruit, Candy, Milk of Etawa Goat 


\section{PENDAHULUAN}

Permen adalah salah satu produk pangan sejenis gula-gula (confectionary) yang berkalori tinggi dan banyak sekali disukai dikalangan masyarakat baik dari anak anak sampai orang dewasa, karena permen dapat dikonsumsi setiap saat tanpa mengenal waktu dan tempat. Melihat dari banyaknya minat masyarakat terhadap produk-produk permen tertentu tidak menutup kemungkinan usaha pembuatan permen ini dapat menjadi peluang bisnis yang menguntungkan. Permen merupakan makanan ringan yang sangat menyenangkan untuk dikonsumsi dan bila dikonsumsi terlalu banyak dapat menimbulkan dampak negatif seperti kerusakan pada gigi terutama pada anak-anak, kegemukan, meningkatkan gula darah.

Dengan kemajuan teknologi informasi dan ditunjang dengan semakin meningkatnya kesadaran masyarakat tentang kesehatan sehingga masyarakat akan semakin kritis dalam memilih produk pangan yang sehat dengan rasa yang menyenangkan. Dengan demikian dampak negatif dari mengkonsumsi suatu produk pangan dapat diminimalisir. Melihat dari kecenderungan tersebut dapat memacu produsen pangan untuk melakukan inovasi produk dengan memperhatikan kandungan gizi yang baik dalam hal ini tidak hanya memiliki rasa enak tetapi juga tidak menimbulkan dampak buruk bagi kesehatan.

Salah satu produk olahan susu adalah permen susu yang berbahan baku utama susu dan gula. Susu yang digunakan dalam produksi permen biasanya tidak mempunyai persyaratan yang ketat, oleh karena itu produk susu yang berkualitas rendah biasanya memiliki kadar air yang tinggi lebih banyak diolah menjadi permen susu (Kersani, 2011). Untuk mendapatkan produk permen yang memenuhi nilai gizi yang baik perlu dilakukan inovasi produk yaitu dengan menggunakan susu kambing etawa sebagai bahan baku utama dan buah kurma sebagai bahan tambahan yang berfungi sebagai pengganti pemakaian gula yang terlalu banyak. Susu kambing etawa dipilih dengan tujuan untuk dapat menghadirkan produk permen bagi anak-anak yang mempunyai alergi terhadap susu sapi. Menurut Journal of American Medicine (1946) susu kambing etawa memiliki banyak manfaat bagi kesehatan diantaranya memiliki sifat anti inflamasi, mengandung asam lemak esensial sekitar 35\% dari total asam lemak dan lebih tinggi dari susu sapi yang hanya $17 \%$, dapat memperbaiki pencernaan, membuat tulang lebih kuat, menjaga kesehatan jantung dan dapat menurunkan berat badan.

Sedangkan pemilihan buah kurma sebagai bahan tambahan penggati gula dipilih karena merupakan buah multiguna yang dapat meregulasi proses pencernaan dan dapat meningkatkan energi dalam waktu 30 menit setelah mengkonsumsinya. Menurut Damayanti (2002), kurma memiliki manfaat anti anemia, anti alergi, menjaga kesehatan dan kekuatan tulang membantu kesehatan jantung dan saraf, menghindarkan gangguan usus, mengatasi diare dan lain sebagainya.

Permen merupakan salah satu produk maka yang berkalori tinggi berbahan baku gula (sukrosa), air, dan sirup fruktosa yang dicampur dengan perbandingan komposisi tertentu dan ditambahkan bahan perasa dan pewarna tergantung pada jenis permen yang diinginkan. Secara garis besar jenis permen ada dua macam yaitu permen keras dan permen lunak. Menurut SNI 3547-1-2008, permen keras adalah jenis makanan ringan berbentuk padat yang terbuat dari gula sebagai bahan utama atau campuran gula dan dengan pemanbahan bahan pemanais lain dengan atau tanpa bahan pangan lain dan bahan tambahan pangan (BTP) yang diijinkan. Permen ini bertekstur keras, dapat larut bila terkena air liur dan tidak menjadi lunak bila dikunyah. Sedangkan yang dimaksud dengan permen lunak menurut SNI 3547-2-2008 adalah makanan selingan bentuk padat yang terbuat darigula sebagai komponen utama atau campuran gula, dengan penambahan pemanis lain dengan atau tanpa penambahan bahan pangan lain dan bahan tambahan pangan (BTP) yang diijinkan, mempunyai tektur relatif lunak atau menjadi lunak bila dikunyah.

Dalam pembuatan permen ada beberapa jenis bahan yang digunakan tergantung pada jenis permen yang diinginkan. Adapun bahan-bahan tersebut adalah: gula (sukrosa) senyawa kimia yang memiliki rasa manis berwarna putih dan bersifat anhidraus. Gula termasuk golongan karbohidrat yang sangat mudah larut didalam air dan pada suhu $20^{\circ}$ kelarutannya 
mencapai $67,7 \%$. Gula banyak digunakan didalam industri gula-gula (confectionary), termasuk didalamnya adalah industri permen (Candy), walaupun sekarang sudah banyak dikembangkan candy jenis "Sugar Free" yang efeknya lebih baik terhadap kesehatan . Sukrosa merupakan senyawa disakarida yang bila dilakukan hidrolisis menghasilkan senyawa monosakarida yaitu glukosa danfruktosa. Didalam teknologi pangan sukrosa digunakan sebagai pemanis, pembentuk tekstur, pengawet dan membuat cita rasa. Didalam pembuatan Hard Candy atau permen keras pemakaian sukrosa sekitar 50\% sampai $70 \%$ dari berat total. Gula yang murni mempunyai kadar abu yang rendah sangat baik digunakan untuk Hard Candy karena dapat meberi warna yang jernih. Bila kadar abu dari gula cukup tinggi akan terjadi peningkatan inversi gula sehingga warna menjadi gelap dan menimbulkan busa pada proses pemasakannya akibatnya pada saat pengerasan permen akan terbentuk gelembung udara yang terperangkap didalam permen. Bila gula yang terinversi cukup tinggi akan dapat merusak flavor, warna dari permen, dan bila jumlahnya terlalu tinggi produk permen akan lengket dan bahkan tidak bisa mengeras (Rahayu dkk., 2013). Gula sangat mudah mengalami inversi pada proses pemanasan, maka untuk menekan adanya ivsersi pemanasan tidak boleh terlalu tinggi. Sukosa bila dipanaskan pada suhu $20^{\circ} \mathrm{C}$ menyebabkan $72 \%$ gula terinversi dan pada pemanasan pada suhu $30^{\circ} \mathrm{C}$ terjadi $80 \%$ gula terinversi.

Sirup glukosa merupakan senyawa monosakarida yang memiliki banyak turunan dan salah satunya dimanfatakan sebagai bahan baku pembuatan produk confectionary yaitu produk-produk yang dominan memiliki rasa manis. Syrup glukosa dikenal ada dua jenis yaitu High Glucose Syrup (Glucose Syrup) dan High Maltose Syrup (HMS). Glucose syrup merupakan cairan kental yang berwarna jernih dan diperoleh dari proses hidrolisa tepung tapioka oleh asam (HCL), sedangkan HMS juga merupakan cairan kental berwarna jernih yang diperoleh hidrolisa tepung tapioka oleh enzim. Penggunaan syrup glukosa pada pembuatan permen sangat penting dalam menentukan kwalitas permen diantaranya mengurangi sifat kehigroskopisan permen yang pada akhirnya dapat meningkatkan umur simpan dari permen, dapat menentukan tekstur permen yaitu permen menjadi lebih liat tetapi kekerasannya cenderung menurun sehingga harus diatur sedemikian rupa perbandingan pemakaian sirup glukosa dengan gula. Apabila perbandingan pemakaian gula banyak dan syrup glukosanya sedikit, hasil yang diperolehnya kuarng elastis dan mudah putus (short dough) sehingga menyulitkan "Cat \& Wrap". Bila perbandingan syrup glukosa banyak dan gulanya sedikit adonannya menjadi liat (Rahayu dkk., 2013). Syrup glukosa berfungsi mengatur tingkat kecepatan proses kristalisasi sesuai dengan kebutuhan. Jika tidak menggunakan syrup glukosa proses pengkristalannya sangat cepat pada saat dilakukan pendinginan sehingga proses pencetakan akan tergaganggu karena cepat mengeras, tidak elastis dan produknya mudah pecah. Dalam pembuatan Hard Candy pada umumnya perbandingan pemakaian sukrosa dengan syrup glukosa adalah 70:30 sedangkan pada pembuatan Soft Candy 50:50.

Menurut penelitian yang dilakukan Amos (2008) didapatkan hasil kualitas candy yang terbaik pada pemakaian minyak pala $1,5 \%$ dengan menggunakan perbandingan gula dengan syrup glukosa 75:25. Sedangkan penelitian yang dilakukan Nurwati (2011) formulasi Hard Candy dengan penambahan ekstrak buah pedada, diperoleh kuaalitas terbaik pada konsentrasi buah pedada $30 \%$ dengan perbandingan gula dengan syrup glukosa 1:1 (journal.uajy.ac.id).

Sebagaimana sifat yang dimiliki air adalah sebagai pelarut yang sangat baik termasuk juga dapat melarutka gula dengan sangat baik sehingga didapatkan larutan gula yang betul- betul homogen, walaupun demikian kebanyakan industri permen menggunakan gula bubuk dengan tujuan agar lebih mudah melarutkannya. Air yang dapat digunakan adalah air yang memenuhi persyaratan sebagai air minun yaitu $\mathrm{pH}$ netral, karena jika $\mathrm{pH}$ asam akan dapat menimbulkan inversi gula yang dapat mengakibatkan warna permen menjadi gelap dan jika $\mathrm{pH}$ basa dapat menimbulkan kerak pada proses pemanasannya. Bahan lain yang kadang digunakan adalah emulsifier, adapun 
Farida Amir, Eka Noviani, \& Nyoman Sri Widari: Pembuatan Permen Susu Kambing Etawa dengan Menggunakan Buah Kurma sebagai Pengganti Gula

tujuan pemakaian emulsifier adalah untuk menstabilkan distribusi lemak dan gula.

\section{METODE}

Penelitian dilaksanakan di Laboratorium Fakultas Teknik, Prodi Teknik Kimia Universitas WR Supratman Surabaya dengan mengambil bahan bahan yang ada disekitar Surabaya,untuk buah kurma serta susu kambing etawa dapat didapatkan di daerah wisata sunan ampel yang terletak disurabaya utara.

\section{Bahan dan alat}

Bahan yang digunakan dalam percobaan ini adalah susu kambing etawa segar, buah kurma, gula pasir, syrup glukosa dan bahan-bahan kimia lain seperti $\mathrm{H}_{2} \mathrm{SO}_{4}, \mathrm{Na}_{2} \mathrm{~S}_{2} \mathrm{O}_{3}, \mathrm{HCl}$, KI serta aquades. Sedangkan alat alat yang dipergunakan adalah neraca analisis, belender, kompor, panci, gelas ukur, erlenmeyer, pengaduk, termometer, loyang dan cetakan permen.

\section{Prosedur penelitian}

Susu kambing segar diukur berat jenisnya dan digunakan untuk menentukan berat dari susu segar dan dilanjutkan dengan mempersiapkan buah kurma yang sudah dibersihkan (dipisahkan kulit dan bijinya). Menimbang gula dan syrup glukosa dengan perbandingan berat 50:100 gram (sebagai variabel tetap) untuk setiap run percobaan. Pada percobaan ini ditetapkan variabel berubahnya adalah berat susu kambing segar (50, 100, dan 150) gram dan berat buah kurma yang sudah bebas kulit dan biji (50, 100, 150, dan 200) gram. Susu segar dan buah kurma diblender sampai halus sesuai dengan variabel berubahnya yang dijalankan. Panaskan campuran gula dengan syrup glukosa dengan perbandingan (50:100) gram didalam panci sampai mendidh $\left(110^{\circ} \mathrm{C}\right)$ dikuti dengan pengadukan sampai semua gula melarut selanjutnya dimasukkan canpuran susu dengan buah kurma yang telah dibelender halus sesuai dengan variabel. Pemanasan tersus dilakukan dengan api kecil sambil diaduk agar adonan tidak gosong. Bila adonan sudah mengental dan kalis segera diangkat selanjutnya dimasukkan kedalam cetakan. Bila adonan sudah mengeras diambil sampel analisis. Adapun parameter yang dianalisis adalah persentase total gula reduksi, persentase total sugar, persentase kadar air, serta uji organoleptik yang meliputi rasa, warna dan aroma. Untuk analisis persentase total gula reduksi dan persentase total sugar digunakan metode Luff Schoorl). Dari hasil analisis terbaik yang didapatkan akan dilanjutkan dengan menganalisis kadar protein dan kadar abunya.

\section{Analisis gula reduksi metode Luff Schoorl}

Timbang 2 gr permen yang telah digerus kedalam beakerglass, kemudian tambahkan aquades dan aduk hingga larut. Masukkan kedalam labu ukur $100 \mathrm{ml}$ dan tera sampai tanda batas dan pipet $10 \mathrm{ml}$ larutan sampel kedalam erlenmeyer $250 \mathrm{ml}$ yang telah berisi $25 \mathrm{ml}$ luff schoorl serta tambahkan $15 \mathrm{ml}$ aquadest. Refluks sampai mendidih selama 10 menit (gunakan stopwatch), angkat dan dinginkan menggunakan air es. Tambahkan $10 \mathrm{ml} \mathrm{KI}$ $20 \%$ lalu tutup mulut erlenmeyer menggunakan alumunium foil dan tambahkan $25 \quad \mathrm{ml}^{2} \mathrm{H}_{2} \mathrm{SO}_{4} \quad 25 \%$ melalui dinding Erlenmeyer. Aluminium dilubangi untuk memasukkan ujung buret kemudian titrasi dengan $\mathrm{Na}_{2} \mathrm{~S}_{2} \mathrm{O}_{3} \quad 0.1 \quad \mathrm{~N}$ sampai berwarna kuning muda, kemudian tambahkan $1 \mathrm{ml}$ indicator amylum $1 \%$, dan titrasi kembali dengan $\mathrm{Na}_{2} \mathrm{~S}_{2} \mathrm{O}_{3} \quad 0.1 \quad \mathrm{~N}$ sampai berwarna kuning muda dan warna biru hilang (warna putih stabil dalam waktu 60 detik). Lakukan penetapan blanko dengan perlakuan yang sama seperti sampel $(25 \mathrm{ml}$ larutan luff school dan $25 \mathrm{ml}$ aquadest).

\section{Analisis kadar sukrosa metode Luff Schoorl}

Timbang 2 gr permen yang telah digerus kedalam beakerglass, kemudian tambahkan aquades dan aduk hingga larut. Masukkan kedalam labu ukur $100 \mathrm{ml}$ dan tera sampai tanda batas lalu pipet $25 \mathrm{ml}$ dan masukkan kedalam erlenmeyer $100 \mathrm{ml}$, tambahkan $\mathrm{HCl} 25 \%$ 3-5 ml lalu tutup menggunakan pipa kapiler. Hidrolisa dalam waktu 15 menit lalu angkat. Masukkan 10 $\mathrm{ml}$ larutan sampel kedalam erlenmeyer 250 $\mathrm{ml}$ yang telah berisi $25 \mathrm{ml}$ luff schoorl dan tambahkan $15 \mathrm{ml}$ aquadest, selanjutnya direfluks sampai mendidih selama 10 menit (gunakan stopwatch). Angkat dan dinginkan menggunakan air es, dan tambahkan $10 \mathrm{ml}$ 
KI 20\% lalu tutup mulut erlenmeyer menggunakan alumunium foil selanjutnya tambahkan $25 \quad \mathrm{ml}^{2} \mathrm{H}_{2} \mathrm{SO}_{4} \quad 25 \%$ melalui dinding Erlenmeyer. Aluminium dilubangi untuk memasukkan ujung buret kemudian titrasi dengan $\mathrm{Na}_{2} \mathrm{~S}_{2} \mathrm{O}_{3} \quad 0,1 \quad \mathrm{~N}$ sampai berwarna kuning muda. Tambahkan $1 \mathrm{ml}$ indikator amilum 1\%, sanjutkan kembali titrasi dengan $\mathrm{Na}_{2} \mathrm{~S}_{2} \mathrm{O}_{3} \quad 0,1 \quad \mathrm{~N}$ sampai berwarna kuning muda dan warna biru hilang (warna putih stabil dalam waktu 60 detik). Lakukan penetapan blanko dengan perlakuan yang sama seperti sampel $(25 \mathrm{ml}$ larutan luff school dan $25 \mathrm{ml}$ aquadest).

\section{Analisis kadar air}

Setting alat Moisture analyzer pada kondisi 0 menit dan suhu $105^{\circ} \mathrm{C}$, selanjutnya ditekan enter. Timbang sample yang telah digerus diletakkan pada aluminium foil dan Moisture analyzer ditutup, tunggu sampai muncul tanda "end" kemudian dicatat kadar airnya.

\section{Analisis kadar protein}

Timbang sampel sebanyak 50 gr dan tambahkan 2 gr capuran selen (selen + $\mathrm{K}_{2} \mathrm{SO}_{4}+\mathrm{CuSO}_{4}$ ), selanjutnya tambahkan 10 $\mathrm{ml} \mathrm{H}_{2} \mathrm{SO}_{4}$ pekat dan dekstruksi selama 2 jam lalu dinginkan. Destilasi sampel dengan penampung asam borat $2 \%$ sebanyak $50 \mathrm{ml}$ dan tambahkan indicator Conway. Titrasi dengan $\mathrm{HCl} 0.1 \mathrm{~N}$ yang telah distandarisasi.

\section{Analisis kadar abu}

Cawan dioven selama 1 jam, timbang dan catat beratnya. Timbang sample sebanyak $2 \mathrm{gr}$ dan pijarkan dalam tanur/muffle dengan suhu $550^{\circ} \mathrm{C}$ selama 6 jam sampai diperoleh abu berwarna keputihputihan. Angkat sample lalu dinginkan dalam desikator selama 10 menit, kemudian timbang cawan beserta sample.

\section{HASIL DAN PEMBAHASAN \\ Analisis persentase total gula reduksi}

Pada dasarnya proses pembuatan permen berdasarkan reaksi karamelisasi yang merupakan reaksi komplek, yaitu reaksi antara group amino (protein, asam amino, peptida) dengan gula dan reaksi ini disebut reaksi Maillard (Anonin, 2013). Akibat dari pemanasan yang tinggi dapat menimbulkan terjadinya perubahan dari gula menjadi bentuk amorf yang berwarna coklat. Pada proses pemasakan adonan pemanasan dilakukan sampai adonan menjadi kental dan kalis, hal ini mengakibatkan terbentuknya gula reduksi. Semakin tinggi suhu pemanasan adonan akan semakin banyak terbentuk gula reduksi/ gula invers, hal ini mengakibatkan kwalitas permen menjadi menurun karena proses pengerasan permen menjadi tergagu dalam hal ini permen sulit mengeras dan produk permen juga cepat lengket pada kemasannya akibatnya masa simpan permen akan berkurang. Gambar 1 merupakan persentase total gula reduksi pada permen, susu kambing segar dan kurma.

Dari hasil percobaan yang dilakukan, dapat dilihat pada Gambar 1 keadaan terbaik ada pada perbandingan komposisi susu kambing segar dengan buah kurma (150:50) gram dengan \% total gula reduksi menunjukkan 16,53\%. Bila hasil tersebut dibandingkan dengan persyaratan yang ditetukan pada SNI 3547.1.2008 yaitu untuk Hard Candy (permen keras) kadar gula reduksi yang diijinkan maksimal 24\%, sedangkan dari hasil percobaan untuk semua run, kadar total gula reduksinya semua memenuhi persyaratan yang telah ditentukan dalam hal ini semua dibawah $24 \%$. 
Farida Amir, Eka Noviani, \& Nyoman Sri Widari: Pembuatan Permen Susu Kambing Etawa dengan Menggunakan Buah Kurma sebagai Pengganti Gula

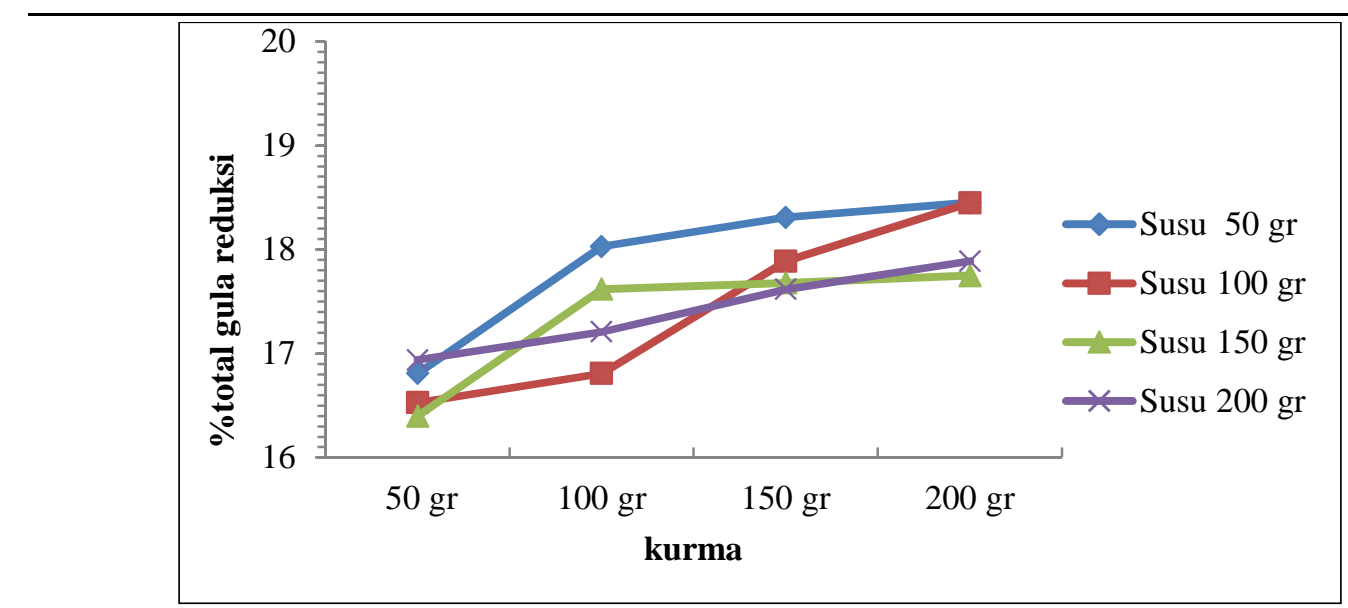

Gambar 1. Persentase total gula reduksi pada permen dengan perbandingan berat susu kambing segar dan berat kurma

\section{Analisis persentase total sugar}

Gula merupakan salah satu bahan paling utama yang digunakan didalam pembuatan permen. Mengingat sukrosa ini memiliki nilai kalor yang tinggi dan bila dikonsumsi dalam jumlah yang berlebih dapat menimbulkan efek samping seperti kegemukan/ obesitas, diabet juga caries pada gigi. Untuk menekan pengaruh negatif dari mengkonsumsi permen yang terlalu banyak, pada percobaan ini digunakan buah kurma untuk menggantikan peran dari gula. Dipilihnya buah kurma sebagai pengganti sukrosa karena buah kurma memiliki rasa sangat manis dan memiliki manfaat yang banyak dibidang kesehatan. Gambar 2 adalah persentase total gula jika dibandingkan dengan susu kambing segar dan kurma. Dari hasil percobaan yang ditampilkan pada Gambar 2 terlihat bahwa pada perbandingan komposisi susu kambing etawa segar dengan buah kurma (50: 200) gram hasil analisis total sugar 76,05\%. Hasil ini dianggap maksimal karena tujuan dari pecobaan ini adalah memproduksi permen sehat dengan melakukan substitusi gula oleh buah kurma, jadi yang terbaik adalah permen yang mempunyai kadar total sugar yang terendah. Dari semua run percobaan yang dilakukan semuanya memiliki hasil analisis total sugar berada diatas $35 \%$ sesuai dengan SNI 3547.1.2008 bagi Hard Candy.

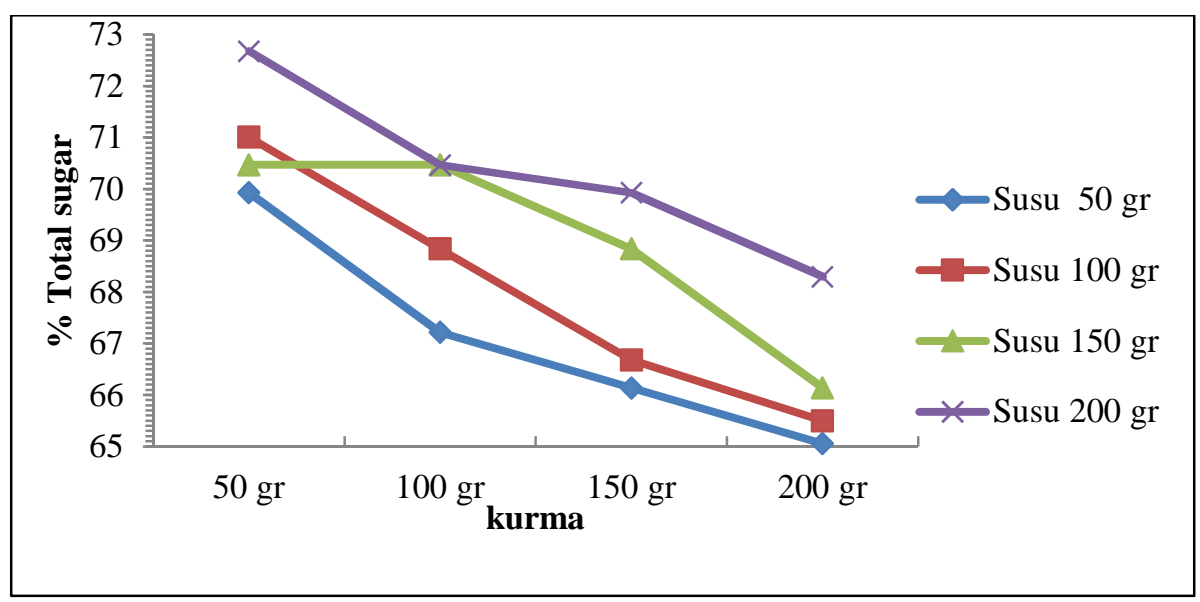

Gambar 2. Persentase total sugar pada permen dengan perbandingan berat susu kambing segar dan berat kurma

\section{Analisis persentase kadar air}

Prinsip proses pemanasan pada pembuatan permen adalah untuk menguapkan air yang terkandung pada susu segar sehingga didapatka adonan dengan kadar air yang rendah. Kadar air pada produk permen sangat mempengaruhi kwalitas permen. Kadar air yang tinggi dapat mengakibatkan bakteri, jamur dan jenis-jenis mikroba lainnya tumbuh dan berkembang 
biak. Keadaan ini dapat mengakibatkan perubahan kimia pada produk seperti perubahan warna dan flavor serta daya awet dari permen juga menurun. Gambar 3 merupakan persentase kadar air pada permen dengan perbandingan berat susu dan kurma. Dari hasil percobaan yang dilakukan, terlihat pada Gambar 3 menunjukkan kadar air yang terendah $1,35 \%$ ada pada perbandingan susu kambing etawa segar dengan buah kurma (50: 200) gram. Dari semua run percobaan yang dilakukan diperoleh bahwa kadar airnya semua memenuhi persyaratan yaitu berada dibawah standar maksimal $(3,5 \%)$ menurut SNI 3547. 1. 2008 bagi Hard Candy.

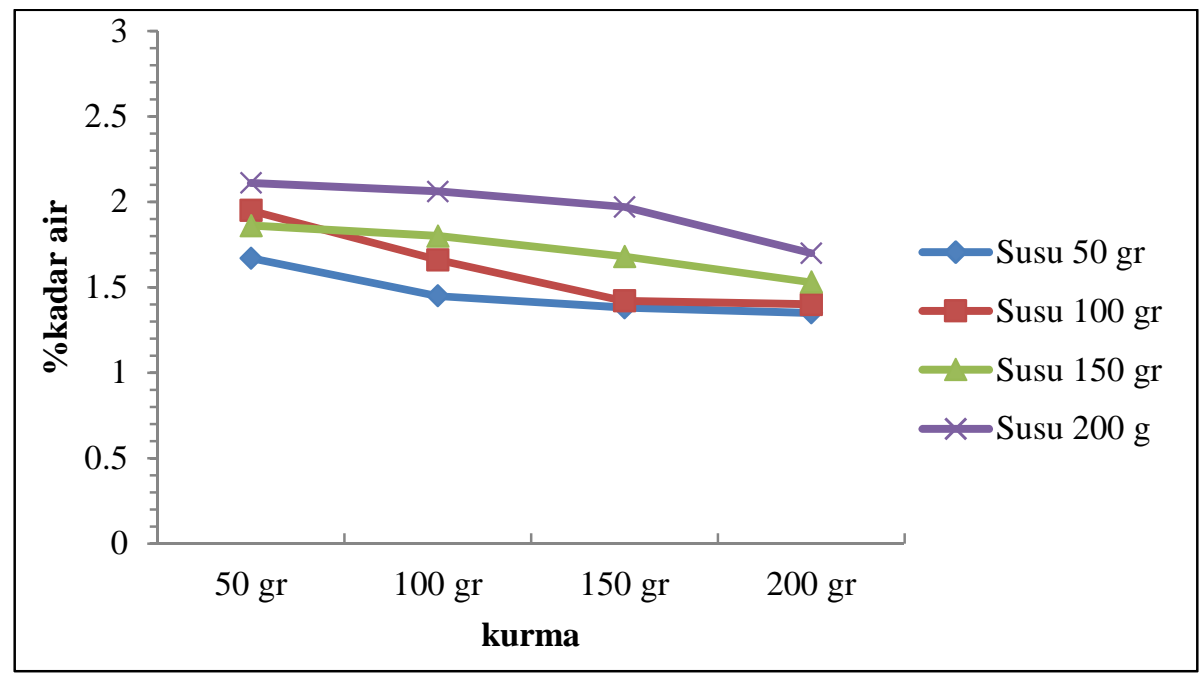

Gambar 3. Persentase kadar air pada permen dengan perbandingan berat susu kambing segar dan berat kurma

\section{Uji organoleptik}

Uji organoleptik dilakukan untuk mengetahui penilaian terhadap produk permen yang dihasilkan meliputi tingkat kesukaan panelis terhadap warna, aroma dan rasa yang dihasilkan dari masing-masing produk. Warna merupakan komponen yang sangat penting dalam menetukan kualitas atau derajat penerimaan dari suatu bahan pangan. Penentuan mutu dari bahan pangan tergantung dari beberapa faktor, tetapi sebelum faktor lain diperhitungkan secara visual faktor warna tampil lebih dahulu dalam menentukan mutu bahan pangan (Winarno, 2004).

Aroma merupakan suatu komponen tertentu yang mempunyai beberapa fungsi dalam makanan, diantaranya dapat bersifat memperbaiki atau mempertajam aroma sehingga mampu menarik kesukaan konsumen terhadap makanan tersebut. Pengujian terhadap aroma pun dianggap penting karena dapat dengan cepat memberikan penilaian terhadap suatu produk oleh konsumen (Winarno, 1997)

Dalam penilaian rasa lebih melibatkan indera lidah. Umumnya makanan merupakan gabungan dari berbagai rasa yang terpadu sehingga menimbulkan rasa yang enak. Rasa merupakan salah satu faktor yang mempengaruhi penerimaan seseorang terhadap suatu makan. Dari analisis organoleptik yang dilakukan terhadap 50 orang panelis, produk permen dengan perbandingan 50 gram susu kambing etawa dan 200 gram kurma ternyata $90 \%$ panelis mengatakan suka dengan warna produk, $70 \%$ panerlis memberi penilaian suka dengan aromanya dan $80 \%$ panelis memberi penilaian suka dengan rasa permennya.

\section{KESIMPULAN}

Dari hasil penelitian dan pembahasan diatas dapat disimpulkan bahwa didalam pembuatan permen yang terbuat dari susu kambing etawa segar dengan bahan pengisi buah kurma yang berfungsi sebagai bahan pengganti sebagian dari pemakaina gula pasir dengan tujuan untuk mendapatkan produk permen sehat agar dapat dikonsumsi dari kalangan anak- anak sampai dewasa, khususnya bagi anak yang alergi dengan susu sapi dan juga bagi orang yang menderita diabet termasuk juga bagi orang 
yang sedang menjalani diet. Dari hasil analisis produknya didapatkan bahwa semua hasil analisisnya memenuhi persyaratan yang ditetapkan pada standart SNI. Walaupun demikian dalam penelitian ini diambil kesimpulan bahwa hasil terbaik berada pada komposisi 50 gram susu kambing etawa segar dan 200 gram buah kurma dengan hasil analisis kadar total gula reduksi $18,46 \%$, kadar total sukrosa $76,05 \%$, kadar air $1,35 \%$, kadar protein $1,5 \%$ dan kadar abu $0,95 \%$. Begitu juga dengan uji organoleptiknya adalah $90 \%$ suka dengan warna permennya, $70 \%$ suka dengan aromanya, dan $80 \%$ suka dengan rasanya.

\section{Ucapan Terima Kasih}

Penelitian ini mendapatkan dukungan dari Laboratorium Teknik Kimia Universitas WR Supratman Surabaya.

\section{DAFTAR PUSTAKA}

Anonim ${ }^{1}$. 2013. Sweetcandyind. From wordpress: Dalam https://sweetcandyind. files. Wordpress.com/2010/05/29855_sni-3547-1-2008.pdf.

Anonim ${ }^{2}$. 2011. Proses pembuatan candy. Dalam http://www.scribd.com/doc.

Badan Standarisasi Nasional (2008). Tabel syarat mutu kembang gula keras. Jakarta.

Kersani(2011), http://posluhdesdesacijambu.blogspot.com/2011/04/permensusu.html

Kimmerle.B.2003. Candy:The sweet Hystory.Oregon:collectors press

Toussaint S and Maguelonne (2009). A history of food. Wiley Blacwell. New Jersey.

Rini Damayanti Moedji, dipl. CN \& Bernadius T Wahyu Wiryanta, Penerbit PT. Agro Media Pustaka, Oktober 2002

Wikipedia, 2011. Pengertian permen. https://id.wikipedia.org.

Winarno, F.G. 2004. Kimia pangan dan gizi. PT Gramedia Pustaka Utama. Jakarta

Winarno F.G,Fardiaz,S.dan D. Fardiaz. 1980. Pengantar Teknologi Pangan. Gramedia.Jakarta 